\title{
The Agency Problem: Measures for Its Overcoming
}

\author{
Meri Boshkoska ${ }^{1}$ \\ ${ }^{1}$ Faculty Economics-Prilep, Republic of Macedonia \\ Correspondence: Meri Boshkoska, Faculty of Economics-Prilep, Republic of Macedonia. E-mail: \\ meribb@yahoo.com
}

Received: September 19, 2014

Accepted: November 4, 2014

Online Published: December 20, 2014

doi:10.5539/ijbm.v10n1p204

URL: http://dx.doi.org/10.5539/ijbm.v10n1p204

\begin{abstract}
As the corporative company type emerged, the two functions of ownership and management are separated. In the companies with a large number of employees the managers are the ones that manage the capital in the best interest of the shareholders.

In this type of companies, conflict of interest may occur between the managers and the shareholders. Having more information about the work of the company, managers may use it in making decisions for their own benefit, which on the other hand cannot be as beneficial for the shareholders.

Conflict of interest between managers and shareholders leads to so-called agency problem. There are different ways by which shareholders can control the operations of management. Some of the measures that can be used to resolve and prevent this problem are subject of analysis in this paper.
\end{abstract}

Keywords: management, ownership, shareholders, conflict of interest, asymmetrical information, corporate governance

\section{Introduction}

It has long been known that in the large companies the interest of the managers may be different from the shareholders profit maximization goal. In these companies mangers are appointed by the shareholders to make decisions and act within their interests. Lasher (2008) says that this kind of relationship creates a conflict of interest known as agency problem. The agency problem arises when one person (principal) hires and authorizes another person (agent) to act on his/her behalf.

Tipuri and Podrug (2010), are treating the theory of agency problem by which agent (manager and/or employee) seeks to maximize personal goals and achieve economic objectives of the principal and the agent level of commitment is a function of his perceptions about the expected value of awards for achievement of financial targets principals. Agency theory assumes that, by itself, a wealth of principal will not be maximized because the agent and principal: they have different objectives, have different access to information and do not have equal risk affinity. There are two basic sources of the agency problem: moral hazard and adverse selection.

Numerous researches have been made about this problem as well as to the mechanisms used to solve or act to prevent it. According to the Eun-Resnick (2004) it is very important for shareholders to control the agency problem because this problem leads to waste of scarce resources, hamper capital market function and decline the economy growth. Predic and Ivanovic - Djukic (2010) indicate that very useful measure is the code of corporate governance that allows shareholders to perform according their rights and encourages transparency of the top managers. Brigham and Houston (2007) suggest several measures that can motivate managers to act in shareholders' best interest: managerial compensation, direct intervention by shareholders, firing and threat of takeover. Lasher (2008) suggests that the effective management of the agency problem includes monitoring of the agent's work.

The main objective of this paper is to answer the following questions:

- What is the essence of the concept of the agency problem?

- What are the measures that can help to overcome the agency problem?

The research is based on the hypothesis that the solution for the agency problem lie in the combination of several measures. 
In the first part of the paper the concept and the sources of the agency problem will be analyzed and in the second part the attention is drawn to the measures for its solution.

As we have mentioned above there are numerous methods that can help acting against the agency problem. According to this, the aim of this paper is to suggest the possible solutions that can be used for prevention and addressing the agency problem.

The scope of the research will cover the explanation of the mentioned objective and will depend on the knowledge that exists in the financial management literature that examines the managerial practice.

\section{Understanding the Concept of Agency Problem}

In the modern corporations, which are the most complex organizational type, the capital is divided among rather large number of shareholders who may be employed in the company, but also legal entities and/or people may be the owners of the company. Within these large corporations, the interests of the shareholders, managers and directors are interwoven. Just because of the fact that the number of owners is big, the shareholders who cannot be employed at the same time, hire managers who act on their behalf as their agents and that leads to dividing of ownership between the control and management. The managers are the ones who have the control and it is very possible that they may put their personal interests first and higher rather than the interests of the company and its owners. This situation many times leads to conflict of interest between the shareholders (the owners) and the managers of the company. This problem is known as the "agency problem". William Laster (2008) points out the numerous and large benefits that the managers have as a result of the agency relations. Other than the huge financial compensations that some of the top managers get, they have benefits known as perquisites-such as luxury cars, planes, yachts, boats etc.

Agency problems are known to result from information asymmetries (agent/manager always has more information than shareholders), potential wealth transfers from debt instrument holders to stockholders through the acceptance of high-risk and high return projects by managers (Nwidobie, 2013). This kind of activities and managerial decision can be harmful for the company as well as for the stockholders.

Another source of agency problem is well known moral hazard that occurs as a results of information asymmetry. Moral hazard occurs when a person or organization that is insulated from risk may behave differently from what it would it if were fully exposed to the risk. In our case, moral hazard arises because managers and owners have different objectives. For example, the company is considering a new investment that is risky, but can contribute to increasing shareholder value. The investment is in the interest of shareholders but not to managers who may lose their jobs if the activity does not take place as planned. Precisely because of the existence of different objectives managers may decide not to implement this kind of investment even though it would bring harm to the owners of the company.

Another possible situation when the managers may even lose the position in the company is when they make a decision according to and to their own interest. For example, the managers can be against the decision of merging of their company with another one although that would be (or is) in the best of interest of the stockholders. This behavior of the top managers might be a result of the possible and very probable change of the leading managerial positions after any merge (Fabozi, Peterson, 2003).

In order to eliminate or intercept a possible agency problem, and the eventual consequences, this paper presents the measures that the stockholders can take in order to be confident in the optimal and right decisions that the managers make in accordance with their interests.

\section{Controlling of the Agency Problem}

In order to prevent the managers to abuse their position and power and protect their interests, the stockholders may use several different mechanisms. In the text that follows, the measures are divided into two groups first and then analyzed as such:

a) Internal measures:

- Internal audit;

- Change in the salaries and payments of the managers;

- Concentrate ownership;

- Good corporate governance/management.

b) External measures:

- External audit; 
- Market of capital;

- Law/legal frame.

\subsection{Internal Measures for Controlling of the Company}

To secure the continuity and the development of the company, the internal audit is of the great importance to be made. It helps to evaluate the efficiency of the company, to detect and stop the eventually inefficient operations as well as to protect the assets and the capital (Jovanova, 2014).

Existing legal frame for the corporate sector in the Republic of Macedonia provides internal audit only within the Banks Law. In the manual for corporate governance of the companies in Macedonia some of the examples from the banking sector are pointed out as ones that can be adjusted and used by the companies (Tikvarovska, 2007).

One of the measures that can be taken to overcome this problem is the way of financial rewarding of the managers. The best way is to calculate their bonuses as a percentage of the realized profit of the company. Why is this rewarding method beneficial? The answer to this question can be illustrated by a simple example of a situation when we ask an agent to help us sell our computer. At the beginning we can arrange with the agent a certain amount that he/she would get for his/her engagement for selling the computer. In this case, the agent will not be interested to ask and get a better price for the computer from the potential buyer and he/she will only be interested in just selling the computer as quick as possible in order to get his/her money arranged previously. Even we, as sellers, will be in a better position if we offer $10 \%$ of the reached value of the computer to the agent. This agreement makes the agent more motivated to reach and sell the computer at a higher price, which makes his/her commission bigger (Westerfield \& Jaffe, 2008)

Accordingly, the same will happen with the top managers if their rewarding depends on the profit of the company. This type of calculated rewarding will motivate the mangers to make decisions and take activities that lead toward the better company profit-the goal that the shareholders strive to as their main interest.

Another established practice is to offer the managers to buy shares and become owners themselves. This is the way of aligning the interests of the managers and the shareholders-long-term development, continuity and increasing the value of the shares.

Eun and Resnick (2004) indicate that concentrated ownership is an effective way to prevent the agency problem. According to them, managerial ownership share increases, their interest aligned with the shareholders interest, so they will act in a way that will increase the shareholder value.

A good system of corporate governance is of great importance for an efficient control of the companies, for the enhancement of their performances, as well as for a better approach and availability of the external financing.

Corporate governance is a term that regards to the relations and roles of each and every party involved as interested in the company. In the code of conduct of the Macedonian banks, corporate governance means standardization of the processes, the procedures and the behavior of the companies. The principles of the corporate governance are as follows: responsibility, transparency and control within the decision making process, as well as reporting about the daily work of the company.

Larcker and Tayan (2011) defined corporate governance as the collection of control mechanisms that an organization adopts to prevent or dissuade potentially self-interested managers from engaging in activities detrimental to the welfare of shareholders and stockholders The level of alignment of the interests of the interested parties within the company shows how good the corporate governance is. In the most cases there are a large number of involved and interested parties such as: shareholders, board of directors, board of managers, the managers, the government, the employees, the clients, the suppliers, the regulation officers, the media, the investors etc. (Figure1) 


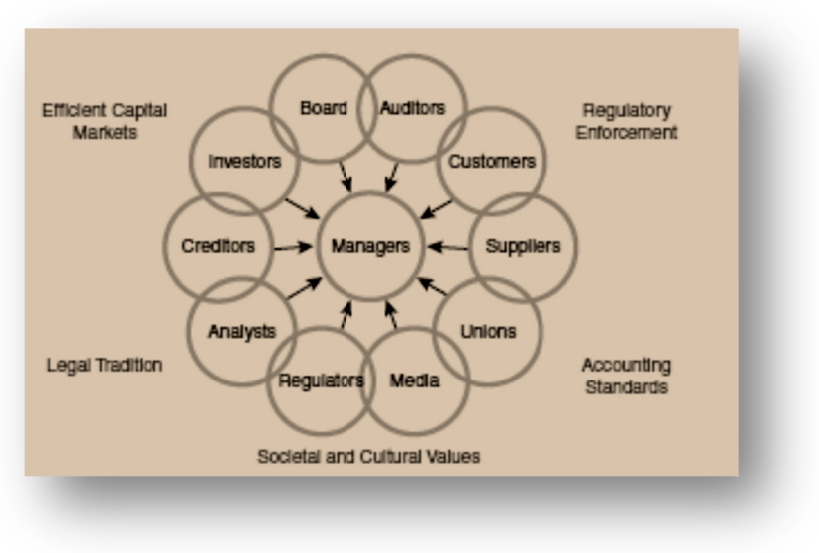

Figure 1. Selected determinants and participants in corporate system (Note 1)

In this context, here we would like to point out that the essence of the good corporate governance consists of the models of governing, and that is why, further in this paper, two models are presented:

- One- level model of corporate governing;

- Two-level model of corporate governing.

Within the one-level model there is one governing/managing board where the members are elected/selected employees of the company that are executive directors, as well as outside the company members-outside directors (Dzordevic, 2012).

The non-executive directors of the board are proposed by the shareholders and most often member of the board is the top manager who very often is its president. The executive directors are appointed by the executives. The downside of this model is that the top manager actually controls him/herself which can often lead to putting his/her own interests first rather than the interests of the shareholders. This model is the most frequent one in the American, Canadian and British companies.

The two-level model occurs more as a characteristic in the European companies where two combinations are possible: the first one is when the board of directors is dominant, and the second one when the control board is dominant. What is the difference between the first and the second one?

When the dominant body is the control board, the shareholders are the ones who appoint and/or dismiss its members. Members of the control board can be even people from outside the company who can actually be more objective when appointing the members of the board of directors, can follow through their work and can decide upon the amount they would get for their work. The managers of the company are members of the board of directors and the president is the top manager. The positive side of this model is that the objectivity of the members of the control board can prevent the decisions made by the top managers that can possibly harm the company. However, there is a downside of this model, too-the cost for the work of this control board that the company must take into account.

The second possibility or combination of the two-level model is when the board of directors is the dominant one and its members are the managers of the company with the top manager as the president of this board who, actually, controls him/herself and/or the decisions and activities taken, again, by him/herself. This is the same problem that occurs with the one-level model of governance but it can be overcome only if the top manager is not a member of the board of directors. The other downside in this situation is that the board of directors appoints the members of the control board and decides upon the financial reward of the members of the control board, executive board and the board of directors. The members of the executive board, one of whom is the top manager, prepare the financial reports that are further on controlled by the external audits. External audits process the financial reports and give their report to the control board. The responsibility of the control board is to control the work of the board of directors and the audits' reports.

Which of these models of governance is the most efficient is a matter of valuation made by the rating agencies according to their indexes. One example of such agencies is Standard \& Poor's. A company Corporate Governance Score (“CGS”) reflects Standard \& Poor's assessment of a company's corporate governance 
practices and the extent which these serve the interests of the company's financial stakeholder, with an emphasis on shareholders' interests. (Standard \& Poor's, 2004)

\subsection{External Measures to Control the Company}

It is essential to obey home and international standards and rules of work, in order for a company to grow and develop. These standards and rules can help controlling the work of the managers, together with prevention of the agency problem.

One of the measures taken to control the work of the company and prevent the agency problem is an effective external control of the work of the managers. The most effective way in this situation is to engage external audits who would periodically value the reality and objectivity of the company's financial reports. Precise financial reporting is critical to ascertaining that the results are stated fairly and the management has not manipulated results for personal gain (Larcker \& Tayan, 2011).

The audit reports are delivered to the shareholders, the managers, the employees, and to the ones who are involved at the market in order to use them as a part of the valuation of the company.

Market price of the shares of a company, according to which the company is valuated, is a signal of a successful work of the company. If the company is governed by a manager whose decisions make the company less efficient, it can lead to a situation when the shareholders would sell their shares. As big the offer of shares is, as lower the price gets, which should be a signal enough for the members of the board of directors that some changes within the managerial department have to be made. Nevertheless, it is very important to point out that in situation like the previously mentioned one, firstly some analysis should be made, meaning whether the lower price comes as a result of bad managing or as a result of the change of some external factors.

Republic of Macedonia and its economy went through a process of privatization in the 90's and striving to become a part of the global, world economy, the question of good corporate governance arouses by itself. That is the reason why we try to modify and use the international standards of corporate governance.

In the Republic of Macedonia the legal frame of the corporate governance is made by:

- $\quad$ Trade Companies' Law;

- $\quad$ The Law on Securities and Exchange;

- $\quad$ The Law on takeover of joint stock companies;

- Bankruptcy Law;

- $\quad$ Corporate Governance Code;

- $\quad$ Rules for quotation the Macedonian Stock Exchange.

International Financial Corporation made manual Guidelines to the Corporate Governance for the Macedonian Companies, in order to help the companies and the banks in Macedonia to improve the practice of corporate governance. The main purpose of this manual is to promote the good corporate governance in Macedonia, something that will make the country more attractive as an investment destination (Tikvarovska, 2007).

Miller (2005) states that there multiple solutions but none is perfect. Therefore, in order to overcome or even prevent this problem, it is necessary to control the work of the managers constantly and to make sure that the company works in accordance with the laws and the international rules in financing.

\section{Conclusion}

The agency problem arises when there is discrepancy between the management and shareholders rest rather in the shareholders' interest. In this case, the management is acting in order to maximize personal wealth.

But whenever there is a problem there is a solution for it. The various research, including ours, point out that there is not a single ideal solution that can help in preventing and solving the agency problem.

In this paper we classified the measures into two groups: internal and external measures. Within the internal ones we analyzed the following measures: internal audit, managerial payments, concentrate ownership and good corporative governance. External audit, capital market and legislation are the external factors that we analyzed. The combination of the stated internal and external measures, as well as, the implementation of other similar measures can deliver the desired results in addressing the agency problem.

\section{References}

Begovic, B. (2003). Improvement of the corporate governance. Center for Liberal-Democratic Studies, 
Belgrade.

Brigham, E., \& Houston, J. (2003). Fundamentals of Financial Management. South-Western College Pub.

Brigham, E., \& Houston, J. (2007). Fundamental of Financial Management (11th ed.). USA.

Dzordevic, S. (2012). The importance and role of mechanisms of corporate management in raising efficiency management. Skola Biznisa, N.1, Novi Sad.

Eun-Resnick. (2004). International Financial Management (3rd ed.). The McGraw-Hill Companies Inc.

Fabozi, F., \& Peterson, P. (2003). Financial management \& analysis. Wiley \& Sons, Inc. New Jersey.

Jovanova, M. (2014). Internal audit as a service of management for improvement of economic efficiency of the enterprises in Republic of Macedonia. MA thesis, Faculty of Economics, Prilep, Macedonia.

Larcker, D., \& Tayan, B. (2011). Corporate Governance Matters: A Closer Look at Organizational Choices and Their Consequences. Pearson Education Inc., New Jersey.

Lasher, W. (2008). Practical Financial Management (5th ed.). USA.

Miller, G. (2005). Solution to Principal-Agent Problems in Firms. http://dx.doi.org/10.1007/0-387-25092-1_15

Nwidobie, M. (2013). Agency conflict and corporate dividend policy decisions in Nigeria, Asian Economic and Financial Review, 3(8), 1110-1121.

Predic, B., \& Ivanovic-Djukic, M. (2010). Methods of solving agency problem. Economic themes N1: 1-12, Faculty of Economics, Nis.

Standards \& Poor's Corporate Governance Scores and Evaluations. (2004). Criteria, Methodology and definitions, S\&P Governance Services.

Tikvarovska, O. (2007). Handbook of Corporate Management in Macedonian shareholding companies. International Financial Corporation, USA.

Tipuri \& Podrug. (2010). Theoretical conceptualization and empirical validation of Stewardship Theory. Proceedings of the Faculty of Economics in Zagreb.

Westerfield, R., \& Jaffe. (2008). Corporate Finance. The McGraw - Hill Companies, Inc.

\section{Note}

Note 1. Larcker, David and Tayan, Brian (2011): Corporate Governance Matters: A Closer Look at Organizational Choices and Their Consequences, Pearson Education Inc., New Jersey, p. 9.

\section{Copyrights}

Copyright for this article is retained by the author(s), with first publication rights granted to the journal.

This is an open-access article distributed under the terms and conditions of the Creative Commons Attribution license (http://creativecommons.org/licenses/by/3.0/). 